\title{
Efektifitas Konseling Kelompok Gestalt Teknik Empty Chair dan Role Revelsal untuk Meningkatkan Self Esteem Siswa
}

\author{
Maskhairani Harahap ${ }^{1}$, Mungin Eddy Wibowo ${ }^{2}$, Mulawarman $^{3}$ \\ ${ }^{123}$ Pasca Sarjana Universitas Negeri Semarang \\ Email: Maskhairaniharahap80@gmail.com
}

\begin{abstract}
Abstrak. Self-esteem merupakan salah satu aspek kepribadian yang memiliki peran penting dan berpengaruh besar terhadap sikap dan perilaku individu. Selain itu, self-esteem juga dikatakan sebagai prediktor perilaku atau kinerja yang baik, karena dapat memberikan kesejahteraan psikologis bagi individu. Tujuan dari penelitian ini adalah untuk mengetahui keefektifan dari konseling kelompok gestalt teknik empty chair dan role reversal di dalam meningkatkan self-esteem siswa. Metode penelitian yang digunakan adalah eksperimen dengan desain pretest and multiple posttest. Subjek dalam penelitian ini adalah siswa XI SMA Kesatrian 1 Semarang yang berjumlah 14 orang. Teknik pengumpulan data menggunakan adopsi dari instrument Coopersmith Self Esteem Inventory (CSEI). Adapun teknik analisis data menggunakan mixed Anova. Lebih lanjut, dari hasil penelitian diperoleh data bahwa konseling kelompok Gestalt teknik empty chair dan role reversal efektif di dalam meningkatkan self-esteem siswa. Selain itu, jika membandingkan kefektifan dari kedua teknik maka teknik empty chair lebih baik dalam meningkatkan self-esteem siswa.
\end{abstract}

\section{Kata kunci: Konseling Kelompok, Gestalt, Empty Chair, Role Revelsal, Self Esteem}

\section{PENDAHULUAN}

Didalam bahasa awam self-esteem sering diartikan sebagai harga diri di mana suatu kesadaran dari dalam diri untuk menghargai diri sendiri yang dinilai berdasarkan perilaku individu yang bersangkutan. Murk (2013) mengatakan selfesteem adalah suatu penilaian yang dilakukan oleh individu dan biasanya yang berkaitan dengan dirinya sendiri. Penilaian tersebut mencerminkan sikap penerimaan atau sikap penolakan, dan seberapa jauh individu percaya bahwa dirinya mampu, penting, berguna serta berharga. Lebih lanjut self-esteem dikatakan sebagai suatu penilaian diri mengenai perasaan berharga atau berarti yang diekspresikan didalam sikap individu terhadap diri sendiri.

Menurut Santrock (2011) self-esteem selain didasari oleh evaluasi terhadap diri, pembentukan self-esteem juga didasari oleh penilaian dan penghargaan orang lain terhadap individu. Self-esteem merupakan suatu komponen yang evaluatif dari konsep diri seseorang baik itu penilaian yang positif maupun negatif tentang dirinya sendiri (Baron \& Byrne, 2005). Selain itu self-esteem dapat dikatakan sebagai proses evaluasi secara global terhadap diri seseorang (Boyd \& Bee,
2007). Adapun individu di dalam melihat selfesteem bukan merupakan suatu bawaan yang telah dimiliki sejak lahir tetapi merupakan suatu komponen kepribadian yang berkembang sejak awal melalui kehidupan manusia. Perkembangan tersebut terjadi secara perlahan-lahan, melalui interaksi dengan orang tua atau keluarga dan orang lain yang memiliki makna bagi individu tersebut, termasuk temanteman sebayanya (Santrock, 2011). Lebih lanjut, dalam hal ini keluarga memiliki peranan yang sangat penting didalam pembentukan self-esteem individu terutama orang tua. Orang tua merupakan model pertama dari proses imitasi, di mana anak akan menilai dirinya sendiri sebagaimana orang tua menilai diri anak tersebut. Sedangakan pembentukan self-esteem yang terkait dengan orang lain dapat dilihat dari lingkungan sosialnya.

Lebih lanjut, masalah self-esteem pada seseorang dapat disebabkan oleh adanya kesenjangan antara pandangan yang dimiliki dengan konsep idealnya terhadap dirinya (Murk, 2006). Adapun kesenjangan tersebut dapat mendorong seseorang menampilkan perilaku tertentu yang ingin ia tampilkan kepada orang lain karena self-esteem memiliki 
korelasi terhadap kepercayaan diri, dengan kata lain jika kepercayaan diri seseorang rendah maka self-esteem akan menjadi rendah (Wang \& Ollendick, 2001). Selain itu, selfesteem yang kuat, dapat berperan dalam keberhasilan dan kegagalan yang dialami seseorang. Individu yang memiliki self-esteem tinggi cenderung memiliki pencapaian akademik yang lebih tinggi dan individu yang memiliki self-esteem rendah memiliki pencapaian akademik yang lebih rendah. Selain berkaitan dengan pencapaian akademik, self-esteem juga berkaitan dengan kesehatan fisik dan mental seseorang.

Konsep harga diri berkaitan dengan tiga konsep lain yang merupakan hal yang tidak dapat dipisahkan, yaitu: self-concept, self-image dan ideal-self (Gitman, 2006). Self -concept adalah istilah payung yang dibawahnya terdapat self-image, ideal-self dan self-esteem. Dalam penelitian ini self-concept adalah keseluruhan dari karakteristik mental dan fisikal individu. Self-image merupakan suatu pemahaman individu terhadap karakteristik mental dan fisikal individu, kemudian ideal-self adalah seperangkat perilaku dan keadaan yang dianggap sebagai standar ideal oleh individu. Lebih lanjut pembandingan antara self-image dan ideal-self yang dilakukan oleh individu itulah yang disebut dengan self-esteem.

Seseorang yang memiliki self-esteem tinggi akan lebih mampu dan mudah untuk menangani serta mengatasi segala permasalahan-permasalahan didalam hidupnya, karena umumnya lebih berkeinginan untuk berani mencoba melakukan cara-cara baru di dalam melakukan sesuatu, dan belajar dari kesalahan untuk mencapai kesuksesan didalam hidup. Karakteristik self-esteem rendah menurut coopersmith (1981) adalah mempunyai perasaan inferior, takut gagal dalam membina hubungan sosial, terlihat seperti orang yang sedang putus asa dan depresi, merasa terasingkan dan tidak diperhatikan, tidak dapat membicarakan diri sendiri, bergantung pada orang lain dan lingkungan, tidak konsisten didalam bersikap, mengikuti lingkungan dengan pasif, menggunakan sikap banyak menentang (mekanisme pertahanan), serta tidak mudah untuk mengakui kesalahan.

Individu dengan self-esteem rendah adalah individu yang kehilangan kepercayaan dirinya dan tidak mampu untuk menilai kemampuan dan atribut-atribut di dalam dirinya, dan gambaran yang individu buat cenderung memberikan kesan depresi dan pesimis. Individu merasa bahwa dirinya bukanlah orang penting dan pantas untuk digemari atau disukai, individu merasa tidak bisa melakukan apapun yang dirinya inginkan, individu tidak yakin akan ide, kemampuan, dan pantas disukai dan individu merasa apapun yang individu lakukan tidak akan mendapatkan perhatian dari lingkungan. Ketika sedang merasa terancam atau buruk individu yang memiliki self-esteem rendah sering sekali mengambil sudut pandang negatif terhadap semua hal, individu akan memperhatikan dan mengingat perilaku yang buruk lainnya.

Sebuah penelitian yang dilakukan oleh Trzesniewski (Simpson \& Scott, 2009) menunjukkan bahwa remaja dengan selfesteem rendah rentan mengalami masalah kesehatan fisik dan mental dimasa dewasanya dan remaja dengan self-esteem yang rendah memiliki kesempatan yang lebih besar untuk mengalami kesehatan mental serta penyalahgunaan obat-obatan dibandingkan dengan remaja yang memiliki self-esteem tinggi. Hal tersebut terjadi karena self-esteem memiliki efek yang lebih kuat pada perubahan perilaku dan lebih spesifik memiliki banyak kesamaan dengan konsep self-efficacy (Fishbein \& Azjen, 1975).

Sesuai dengan pemaparan di atas, lebih lanjut peneliti melakukan studi pendahuluan di SMA Kesatrian 1 Semarang dengan hasil wawancara kepada guru BK diketahui ada banyak siswa kelas XI yang memiliki tingkat self-esteem dengan katagori sedang sampai rendah. Ditunjukkan dengan karakteristik mereka yang mengalami kesulitan untuk mengatur dan mengontrol tingkah laku, cemas dan takut untuk mengeluarkan pendapat, kurang percaya diri, mudah tersinggung, dan merasa tidak dihargai, tidak bisa bekerja didalam kelompok, tidak mampu untuk 
menerima kritikan dan merasa tidak disukai karena merasa sikap dan sifatnya tidak menarik perhatian orang lain, tidak mampu untuk menyelesaikan tugas-tugas yang diberikan padanya, dan tidak percaya diri di dalam membuat atau mengambil keputusan. Dari masalah yang terjadi dilapangan maka dianggap penting untuk meningkatkan selfesteem agar dapat berkembang dengan optimal sesuai potensi yang dimilikinya.

Self-esteem dikatakan sebagai prediktor perilaku atau kinerja yang baik, karena dapat memberikan kesejahteraan psikologis. Lebih lanjut, memiliki self-esteem yang tinggi sangat penting dalam kehidupan siswa karena dapat mengarahkan diri untuk memandang nilai, sikap, serta hubungan interpersonal yang berbeda sebagai motivasi untuk mengembangkan potensi dalam diri (Rosenberg, 1995). Dengan alasan tersebut, maka peneliti memandang perlu untuk meningkatkan self-esteem yang rendah. Selain itu, Leary (2000), menyarankan di dalam meneliti self-esteem harus memperhatikan perbedaan individu dalam self-esteem yang global atau spesifik. Adapun dalam hal ini selfesteem yang akan ditingkatkan adalah selfesteem tekait dengan kemampuan akademiknya di sekolah.

Lebih lanjut untuk membantu siswa meningkatkan self-esteem yang tekait dengan kemampuan akademiknya di sekolah maka akan digunakan konseling kelompok gestalt sebagai intervensinya. Pendekatan gestalt pada dasarnya mendorong suatu individu untuk menyelenggarakan terapi sendiri, seperti introspeksi diri, mencari suatu kesalahan yang ada pada diri sendiri kemudian memperbaikinya. Di dalam hal ini individu tersebut didorong dan dimotivasi untuk membuat penafsiran-penafsirannya sendiri, menciptakan pernyataan-pernyataannya sendiri, dan menemukan setiap maknanya sendiri. Akhirnya, individu tersebut seolaholah langsung mengalami perjuangan di sini dan sekarang terhadap urusan yang tidak selesai di masa lampau atau masa lalu. Dengan mengalami berbagai masalah atau konflik, meskipun hanya membicarakannya, siswa lambat laun dapat memperluas kesadarannya (Corey, 2005).

Pendekatan gestalt dalam hal ini berpijak pada premis bahwa setiap individu harus menemukan jalan hidupnya sendiri dan menerima tanggung jawab pribadi jika individu berharap mencapai kematangan. Pendekatan gestalt berfokus pada apa dan bagaimana-nya tingkah laku serta pengalaman di sini dan juga sekarang dengan memadukan (mengintegrasikan) bagian-bagian dari kepribadian yang terpecah dan tak diketahui, sebab pendekatan gestalt bekerja terutama di atas prinsip kesadaran individu (Corey, 2012). Penelitian Ozgur et al (2017) membuktikan bahwa ada hubungan antara gaya kontak gestalt dengan self-esteem. Berdasarkan penjelasan teori tentang pendekatan gestalt dan hasil penelitian terdahulu, peneliti berasumsi bahwa teknik empty chair dan role revelsal melalui konseling kelompok dapat menjadi alternatif untuk meningkatkan self-esteem siswa.

Peneliti memilih menggunakan pendekatan gestalt, karena lebih menekankan pada individu untuk mampu menerima kenyataan dan mendorong individu untuk menemukan jalannya sendiri sehingga mampu mengintegrasikan dirinya kepada kehidupan yang dialaminya. Selain itu gestalt sendiri memandang manusia sebagai suatu keutuhan dan bukan dari bagian-bagian. Maksudnya adalah bahwa manusia itu sendiri mempunyai berbagai macam-macam ekspresi serta emosi yang terkumpul menjadi satu sebagai manusia itu sendiri.

\section{METODE PENELITIAN}

Penelitian ini merupakan penelitian kuantitatif dengan metode penelitian eksperimen. Menurut Creswell (2015) menyatakan bahwa eksperimen merupakan rancangan kuantitatif terbaik yang bisa digunakan untuk menetapkan kemungkinan sebab-akibat. Hal ini sesuai dengan tujuan dalam penelitian ini yaitu meneliti hubungan sebab-akibat dua variabel yaitu variabel independen yang dalam penelitian ini adalah konseling kelompok gestalt dengan teknik empty chair dan teknik role reversal terhadap 
variabel dependen yaitu self-esteem. Penelitian ini menggunakan rancangan eksperimen pretest and multiple posttest design.

Pada penelitian ini, peneliti menggunakan dua kelompok eksperimen. Sebelum pelaksanaan eksperimen, kelompok eksperimen pertama dan kedua diatur secara intensif sehingga kedua kelompok mempunyai karakteristik yang sama atau mendekati sama. Letak perbedaan dari kedua kelompok ialah bahwa grup eksperimen diberi treatment atau perlakuan tertentu. Sebelum melaksanakan treatment, seluruh subjek diberikan wawancara terkait sifat self-esteem. Hasil dari wawancara dijadikan pertimbangan dalam pemilihan penelitian kelompok eksperimen. Kelompok eksperimen yang sudah dipilih selanjutnya diberikan pretest, yaitu pemberian angket self-esteem. Pretest ini dilakukan untuk mengetahui gambaran self-esteem siswa sebelum diberikan treatment dan untuk dibandingkan dengan pengukuran saat Posttest dan Follow Up.

Setelah kelompok eksperimen dibentuk dan telah dianggap sepadan, maka tahap selanjutnya adalah peneliti melakukan treatment pada kedua kelompok eksperimen. Tujuan pemberian treatment atau perlakuan dalam penelitian ini adalah untuk melihat seberapa besar pengaruh kelompok konseling gestalt teknik empty chair dan role reversal dapat meningkatkan self-esteem siswa. Dalam penelitian ini kelompok konseling gestalt bersifat jangka pendek (short term group counseling). Peneliti akan memberikan treatment pendekatan kelompok konseling gestalt teknik empty chair dan role reversal yang direncanakan 4-5 kali pertemuan, dengan frekuensi pertemuan antara dua sampai tiga kali dalam seminggunya dan durasinya 50 menit setiap pertemuan. Pada tiap akhir pertemuan akan dilakukan penilaian.

Langkah selanjutnya adalah memberikan posttest pada kelompok eksperimen. Bentuk posttest sama seperti pada saat pretest. Adapun posttest dilakukan dengan mengukur perubahan yang terjadi pada konseli setelah diberikan perlakuan (treatment) yaitu konseling kelompok gestalt teknik empty chair dan role reversal. Selanjutnya diberikan follow-up dengan tujuan untuk mengetahui tingkat keberhasilan dalam pelaksanaan treatment setelah posttest dan untuk mengetahui keefektifannya terhadap selfesteem siswa. Selanjutnya peneliti menganalisis data yang telah diperoleh kemudian mendeskripsikan hasil data tersebut dan langkah terakhir adalah menyusun laporan.

Sampel dalam penelitian ini adalah siswa kelas XI di SMA Kesatrian 1 Semarang yang memiliki kriteria self-esteem rendah sebanyak 14 orang. Teknik pengumpulan data menggunakan adopsi dari instrument Coopersmith Self Esteem Inventory (CSEI) tahun 1967. Skala yang digunakan dalam penelitian ini adalah skala tertutup dan menggunakan skala likert dengan lima alternatif jawaban, yaitu sangat sesuai, sesuai, kurang sesuai, tidak sesuai, sangat tidak sesuai. Adapun dalam penelitian ini, teknik analisis data menggunakan mixed Anova.

\section{HASIL DAN PEMBAHASAN}

Penelitian ini bertujuan untuk mengetahui keefektifan konseling kelompok gestalt teknik Empty Chair dan role reversal untuk meningkatkan self-esteem siswa. Maka dilakukan uji hipotesis untuk menjawab rumusan masalah yang telah dipaparkan pada pembahasan sebelumnya. Uji hipotesis yang dilakukan pada penelitian ini menggunakan uji repeated measure melalui Software Proscess SPSS 23. Berdasarkan uji repeated measure menggunakan Anova yang telah dilakukan untuk menjawab hipotesis penelitian, diketahui bahwa deskripsi tingkat rata-rata dan standar deviasi academic self-esteem siswa mengalami peningkatan dengan menggunakan teknik empty chair dari pretest dapat dilihat rata-ratanya $(\mathrm{M}=29.58, \quad \mathrm{SD}=1.27)$, posttest $(\mathrm{M}=42, \mathrm{SD}=1.15)$ dan follow up $(\mathrm{M}=45.48$, $\mathrm{SD}=1.51)$. Sedangkan untuk meningkatkan self-esteem siswa melalui teknik role reversal pun ada peningkatan dari pretest $(\mathrm{M}=29.71$, $\mathrm{SD}=1.11)$, posttest $(\mathrm{M}=41, \mathrm{SD}=0.81)$ dan follow up $(\mathrm{M}=43.42, \mathrm{SD}=0.97)$. Hal ini sebagaimana disajikan dalam tabel 1 . 
Tabel 1. Hasil Uji Repeated Measure SelfEsteem Siswa

\begin{tabular}{ccccccc}
\hline Teknik & $\mathbf{T}_{\mathbf{1}}$ & $\mathbf{T}_{\mathbf{2}}$ & $\mathbf{T}_{\mathbf{3}}$ & $\mathbf{F}$ & $\mathbf{D f}$ & $\mathbf{p}$ \\
\hline $\begin{array}{c}\text { Empty } \\
\text { Chair }\end{array}$ & 29.58 & 42 & 45.48 & 639.88 & 1.2 & $<0.01$ \\
\hline $\begin{array}{c}\text { Role } \\
\text { Reversal }\end{array}$ & 29.71 & 41 & 43.42 & 512.17 & 1.2 & $<0.01$ \\
\hline
\end{tabular}

Berdasarkan pada tabel 1 di atas dapat diketauhi bahwa self-esteem siswa mengalami peningkatan, pada saat diberikan treatment melalui teknik Empety chair $\left(\mathrm{F}_{(1,2)}=639.88, \mathrm{p}\right.$ $<0.01)$ dan menggunakan teknik role reversal $\left(\mathrm{F}_{(1,2)}=512.17, \mathrm{p}<0.01\right)$ dari pretest, posttest dan follow up. Hal tersebut sesuai dengan hasil uji within subject, diketahui bahwa kondisi awal self-esteem siswa kelas XI SMA Kesatrian 1 Semarang sebelum diberikan treatment dengan teknik empty chair $(\mathrm{M}=$ 29.58, $\mathrm{SD}=1.27$ ) dan setelah mendapat intervensi $(\mathrm{M}=42, \mathrm{SD}=1.15)$ yang selanjutnya pada proses akhir intervensi atau follow up juga mengalami peningkatan $(\mathrm{M}=$ 45.48, SD = 1.51). Sedangkan kondisi awal self-esteem siswa kelas XI SMA Kesatrian 1 Semarang sebelum mendapat treatment menggunakan teknik role reversal $(\mathrm{M}=29.74$, $\mathrm{SD}=1.11)$ dan setelah diberikan treatment $(\mathrm{M}$ $=41, \mathrm{SD}=0.81$ ) selanjutnya diberikan follow up mengalami peningkatan $(\mathrm{M}=43.42, \mathrm{SD}=$ 0.97). Dengan demikian Ha diterima yang berarti ada penigkatan antar waktu pada selfesteem siswa, dengan demikian teknik empty chair dan role reversal sama-sama efektif untuk meningkatkan self-esteem siswa melalui konseling kelompok kelompok gestalt.

Berdasarkan hasil penelitian dapat disimpulkan bahwa konseling kelompok gestalt teknik empty chair dan role reversal efektif dalam meningkatkan self-esteem siswa. Namun bila dilihat hasil antar waktunya atau whitin subject, yang lebih dominan untuk meningkatkan self-esteem siswa adalah teknik empty chair. Menurut Thomson (dalam komalasari, dkk, 2014) teknik empty chair efektif digunakan dalam membantu konseli karena dapat mengeksplorasi dan memperkuat konflik antara top-dog dan under-dog di dalam diri klien. Top-dog atau under-dog ini merupakan kiasan untuk menggambarkan konflik internal dalam diri klien antara introyeksi dan perlawanan terhadap introyeksi tersebut. Top-dog menggambarkan "apa yang wajib atau seharusnya dilakukan" sedangkan under-dog menggambarkan penolakan dan pemberontakan terhadap introyeksi tersebut (Agustiani, 2017).

Berdasarkan penelitian yang dicapai oleh subjek penelitian mampu menjadi bukti bahwa saat ingin meningkatkan self-esteem pada siswa, penting kiranya mempersiapkan strategi layanan bimbingan dan konseling yang mampu menyentuh ranah tersebut. Melalui strategi layanan bimbingan dan konseling yang mampu meningkatkan self-esteem membantu siswa agar menjadi lebih tenang saat berada di sekolah, baik dalam hubungan dengan sebaya, senior dan juga guru. Selain itu dengan meningktanya self-esteem siswa akan lebih merasakan happiness (kebahagiaan) selama mengikuti setiap kegiatan yang ada di sekolah dan lingkungan sosialnya.

\section{KESIMPULAN}

Berdasarkan temuan penelitian ini, maka implikasinya bagi konselor adalah saat ingin menangani siswa yang memiliki selfesteem rendah dapat memberikan layanan konseling kelompok gestalt teknik empty chair dan role reversal. Selain itu beberapa hal penting yang perlu menjadi perhatian konselor dalam pelaksanaan layanan konseling konseling dengan teknik empty chair dan role reversal adalah ketersediaan waktu serta kesabaran dalam memberikan layanan kepada siswa, karena memang membutuhkan energi yang sangat luar biasa untuk memodifikasi layanan yang diberikan. Saat konselor menggunakan intervensi konseling kelompok gestalt teknik empty chair dan role reversal maka aspek pertama yang harus diketahui adalah berfokus pada kesadaran dan tujuan saat ini. Hal ini akan berdampak pada aspek peningkatan self-esteem siswa.

\section{DAFTAR PUSTAKA}

Agusrtiani, M. (2017). Teknik terapi empty chair dalam mengatasi korban bullying di SMP Negeri 1 Ciomas. (Skripsi). Banten: IAIN Sultan Maulana Hasanudin Banten. 
Baron, R.A. \& Byrne, D. (2005). Psikologi sosial. Edisi kesepuluh. Jakarta: Erlangga.

Boyd, D., \& Bee, H. (2007). The developing child. USA: Boston Pearson

Coopersmith, S. (1981). The antecedents of self-esteem. Palo Alto: Counsulting Psychologist Perss.

Corey, G. (2005). Teori dan praktek dari konseling dan psikoterapi. Terjemahan oleh E. Koeswara. Jakarta: ERESCO.

Corey. G. (2012). Theory \& practice of group counseling. Eight Edition. Pacific Groove.

California: Books/Cole.

Creswell, J.W. (2015) Riset Pendidikan Perencanaan, Pelaksanaan dan Evaluasi Riset Kualitatif dan Kuantitatif. Yogjakarta: Pustaka Belajar.

Fishbein, M., \& Ajzen, I. (1975). Belief, attitude, intention and behavior. Reading, MA: Addison-Wesley.

Gitman, L.J. (2006). Principles of Managerial Finance. USA, Pearson.

Komalasari, G., dkk. (2011). Teori dan Teknik Konseling. Jakarta: PT Indeks.

Leary, M.R., \& Baumester, R.F. (2000). The nature and function of self-esteem: Sociometer theory. Advances in Experimental Social Psychology, 32, $1-62$.

Murk, C.J. (2006). Self-esteem research, theory, and practice: Toward a positive psychology of self-esteem (3rd ed.). New York: Springer Publishing Company.

Murk, C.J. Christopher J. (2013). Self-Esteem and Positive Psychology Research, Theory, and Practice (4rd ed). New York: Springer Publishing Co.

Rosenberg, M., Schoolar, C., \& Rosenberg, F. (1995). Global self-esteem and specific self-esteem: different outcomes.

Santrock, J. W. (2011). Educational Psychology (5th Edition ed.). New York: Mc Graw Hill
Wang, Y., \& Ollendick, T.H. (2001). A crosscultural and developmental analysis of self-esteem in Chinese and Western children. Clinical Child and Family Psychology Review, 4, 253-271. 